\title{
The evolution of British immigrant integration policy after World War II: a historical and political science perspective
}

Immigration into the UK reached record intensity after World War II. The acceptance of immigrants was motivated by both the country's foreign policy and internal economic situation. Most immigrants to the Isles were inhabitants of the former territories of the British Empire, migrating en masse to the former seat of power in the early postwar decades. The United Kingdom also attracted those who had political reasons not to return to their homelands, subordinated to the Soviet Union after the war. The Isles also welcomed two waves of political migrants fleeing the Eastern Bloc after the bloody conclusion of the Hungarian Revolution of 1956 and the Warsaw Pact intervention in Czechoslovakia in 1968.

The openness of the UK to large numbers of immigrants in the postwar period was also determined by economic considerations. The country, with its rapidly growing economy, needed a labour force. This state of affairs continued into the second half of the 1970s, when the economic crisis necessitated a reduction in the recruitment of foreign workers.

This article aims to demonstrate the evolution of the multicultural model of immigrant integration adopted after World War II by the UK. To this end, the author presents the historical determinants of this model and examines the most important legal regulations which influenced its development in the UK. The author also seeks to interpret the current attitude of British society at large and of the ruling elite to the negative phenomena associated with migration, which escalated at the turn of the 21st century. Acknowledging that multiculturalism, the idea on which the modern British nation is founded, is currently in crisis, the author presents the actions taken by the British authorities in order to overcome this problem.

\section{The United Kingdom and the process of decolonization after World War II}

The United Kingdom actively participated in the process of decolonization of its overseas possessions. The British decolonization model assumed a gradual transfer of power to the local population, with the Empire maintaining control over the entire process, known as the transfer of power (Kiwerska, 1989, p. 291-292). This model of decolonization was shaped by the experiences resulting from the emancipation of the thirteen American states in the late 18th century. 
The theoretical basis for the "transfer of power" policy fully developed in the first decade after World War II (Young, 1970, p. 488). The first postwar Secretary of State, Arthur Creech Jones, advocated for the gradual progress of the colonies towards sovereignty under the "supervision" of the former Empire. To become independent, a colony would need to fulfil a number of conditions, such as:

- suitable level of economic development, self-sufficiency (economic viability) ${ }^{1}$

- the existence of an educated native elite, which would take over government and local administration;

- institutions of power functioning at the central and local levels in the colony;

- demonstrating the pursuit of a "sense of national unity," transcending any religious or tribal affiliation (Kiwerska, 1989, p. 295).

The British decolonization strategy was adequately summed up by the Governor of Uganda, Andrew Cohen: "the British policy must address three areas. Political progress, economic development, and the introduction of education and change into the society are interdependent. None of these elements can succeed without the other two" (Cohen, 1959, p. 90). When the Conservative Party took power in 1951, they maintained the decolonization model promoted by the Labour Party. A characteristic feature of the thirteen-year rule of the Conservative Party was the ambition to maintain Britain's ties to the territories formerly controlled by the Empire. The transfer of power to the natives in the colonies would foster their independence while simultaneously maintaining their bond to the former seat of the Empire as members of the British Commonwealth of Nations.

The British policy of gradual progress towards sovereignty was challenged by the rapid development of national liberation movements, especially in the African colonies. The year 1960, symbolically named the "Year of Africa" was the point at which British policy towards its dependent territories needed to change. The growing aspirations of independence of African colonies were recognized in the memorable speech Harold Macmillan delivered on 3 February 1960 to the Parliament of South Africa. Macmillan spoke about the wind of change affecting the continent, a phenomenon which could also be observed in the British territories in Asia shortly after World War II (Mansergh, 1953, p. 341-351). The wind of change led to a departure from the policy of progressive preparation for independence. Great Britain had to accept the vigorous transformations that resulted in the liberation of British colonies in Africa.

The rule of the Conservative Party also determined the form of the British Commonwealth of Nations. The Commonwealth was established as a result of the "white British dominions" attaining the status of independent states by the end of World War I. The peace conference in Paris in 1919-1920 was the first international meeting which the British dominions attended as independent subjects of international law. In 1926, an

1 As early as 1945, the British Parliament adopted the Colonial Development and Welfare Act. The act regulated the amount of subsidies granted to the colonies for the purposes of economic development, promotion of education, and health care. Another important document was the Overseas Resources Development Act of 1948. At the time, two organizations were established and provided with significant financial resources: the Overseas Food Corporation and the Colonial Development Corporation (Kiwerska, 1989, p. 300). 
all-British conference was held, during which the British Commonwealth of Nations was formally established as an association of countries connected by common political, economic and cultural interests arising from their membership of the former British Empire. The group included the following dominions of Great Britain: Canada, Australia, New Zealand, and the Union of South Africa, as well as the majority of countries of the former British Empire. ${ }^{2}$

The form and functioning of the Commonwealth were recorded in the Statute of Westminster in 1931. The main provisions of the Statute were based on a document drawn up by a committee headed by Arthur Balfour, presented at the Imperial Conference of 1926, and later renegotiated. The Statute introduced equal status for Great Britain and its dominions of the time. Another significant provision of the Statute was the abolition of the principle whereby legal acts enacted by the dominions had to comply with British law on pain of nullity. ${ }^{3}$

After World War II, the Commonwealth entered a new phase. It became a platform enabling Britain to maintain its influence in the former Asian and African colonies. Jadwiga Kiwerska refers to this transformation as "the process of transition from Empire to Commonwealth" (Kiwerska, 1989, p. 316). The first countries from outside the circle of "white dominions" to join the British Commonwealth were India and Pakistan in 1947, and Ceylon (currently Sri Lanka) in 1948. The following year, the word "British" was omitted from the name of the Commonwealth. From that moment on, the Commonwealth of Nations became a multi-racial organization. The renaming was also symbolic of the abandonment of British ambitions of dominance in favour of equal rights for all members of the Commonwealth. The Commonwealth of Nations would become a setting for full decolonization of the former possessions of the British Empire. This approach was announced at the Conference of the Commonwealth in 1945. It was postulated that the transformation of the Empire would proceed in two stages. The first involved the full decolonization and sovereignty of the former colonies, which then, through voluntary accession, would become members of the Commonwealth of Nations. The British supported the formation of power structures in the former colonies based on the British parliamentary system. However, the British model, especially in Africa, was supplanted by a republican form of government. This development necessitated a change in internal relations within the Commonwealth. From 1964 on, the Commonwealth was a union of communities, but not governments (Lee, 1967, p. 232-237).

Specialist literature on the British decolonization model raises the issue of British aspirations to maintain a strategic position in the former colonies and continue close economic cooperation to ensure the safety of British capital. In the face of increasing political and economic empowerment of former British territories and the fact that Africa in particular had become a field of Cold War rivalry between the United States and the Soviet Union, the Commonwealth of Nations was gradually losing its importance (cf. Miller, 1974; Mansergh, 1955). However, it is impossible to ignore the role of this

2 The first four dominions were joined in 1922 by Ireland, which, however, withdrew from the Commonwealth of Nations in 1949 (Stownik historii politycznej..., p. 550).

3 However, Great Britain maintained the exclusive right to amend the Basic Laws of Canada and Great Britain (Chase, 1947). 
institution in the development of the multicultural model for the integration of immigrants from the former British Empire.

\section{Integration of immigrants into the host society: a theoretical approach}

Anthony Giddens theorizes that in modern multiethnic societies, the relations between minority groups and the majority of the population can be grouped under three basic models: assimilation, "melting pot of nations," and pluralism.

Assimilation means that "immigrants depart from their customs and practices and adapt their behaviour to the values and norms of the majority. Integration with a new social order through assimilation requires immigrants to change their language, dress, lifestyle and world view" (Giddens, 2006, p. 279).

In Giddens's "melting pot of nations" model, "the immigrants' traditions of origin are not erased under pressure from the dominant local tradition, but blend into it to form new cultural patterns. In this way, the culture of a society is enriched by the diverse values and norms introduced to it from the outside, while diversity is also created by the ethnic groups themselves through their adaptation to the social environment in which they find themselves" (Giddens, 2006, p. 279).

The final model postulated by Giddens is cultural pluralism, characterized by a commitment to the development of a truly pluralistic society, in which many different cultures enjoy equal rights. In addition, such a society respects ethnic differences as an important component of the life of the whole nation (Giddens, 2006, p. 280).

One of the most recent theories on this problem was developed by Stephen Castles. He identified three ideal types of immigrant incorporation policies: pluralism/multiculturalism, assimilation, and differential exclusion (cf. Castles, 2003).

The policy of multiculturalism (pluralism) is based on respect for the language, culture and religion of the immigrants' country of origin, with the state ensuring their equal rights in all areas of political and social life. Multiculturalism reflects the fact that new immigrants, to some extent, adopt the culture and norms of the host society, and subsequent generations born in the new country preserve elements of their culture of origin. The policy of multiculturalism involves rejecting the ideal of a completely homogenous society as a goal impossible to achieve in practice. ${ }^{4}$

The policy of assimilation assumes that immigrants should adopt the culture and norms of the host country. In the process of their integration into the host society, the newcomers renounce their native culture and former national identity while adopting the language of the host country for use both in public and private life. The policy of assimilation was applied in the 18th and 19th century in countries such as the United States and Canada - major destinations of successive waves of migration. In the 20th

4 Typical countries practicing the policy of multiculturalism today are the United States, Canada, the United Kingdom and Australia. In the latter case, a system of selection is used whereby new citizens are chosen on the basis of human capital represented by the individual: age, level and field of education, and language skills (Castles, 2010). 
century, with the idea of the crucible (melting pot) being increasingly abandoned, this policy evolved towards the multicultural decolonization model of the 1980s.

Most European countries, from the early 1970s on, have shifted away from the idea of integration as a process of assimilation. In wider circles, both political and academic, the assimilation policy was judged incompatible with the principles of democracy. Increasingly, the issue of immigrant rights, such as the right to their own cultural and religious identity, was also raised. These rights were gradually incorporated into the legal framework and procedures regulating the issuing of residence permits and citizenship of the host country.

The policy of differential exclusion permits the integration of immigrants into certain areas of social life - mainly the labour market - while excluding them from the political sphere. Until the end of the 20th century, this policy was used in Germany, where the "gastarbeiter" concept originated - a working person who nonetheless is not entitled to citizenship or the right to participate in political and social life.

\section{Evolution of the British model of immigrant integration in the legal and institutional context}

The British concept of nationality had a significant impact on the evolution of the model of immigrant integration adopted. The British integration policy focuses on ensuring the equality of the various social groups while maintaining social cohesion. In the UK, the increased global migration after World War II did not prompt the adoption of a deliberate policy for the integration of newcomers. There was emphasis on legal solutions regulating relations between different ethnic groups. This approach is deeply rooted in the history of Great Britain and later the British Empire. Their formation was conditional on the coexistence of different ethnic groups. The British state officially came into existence in 1707, when England merged with Scotland. The next step was the formation of the United Kingdom as Ireland joined the union in 1801. The beginnings of the UK's existence as a single state - as noted by Renata Włoch - involved the need for a peaceful co-existence of different groups with strong national identities: the English, the Welsh, the Scots and the Irish (Włoch, 2011, p. 61). The development of the Empire added other groups characterized by an ethnic rather than national identity. Thus, it is interesting to note the observation of Steve Vertovec that today's society has reached a state of "super-diversity," forming a complex mosaic of races, religions, and nationalities (cf. Vertovec, 2006).

The British concept of nationality is reflected in matters relating to acquisition of citizenship. The first legal acts regulating this issue were related to the emancipation of former dominions and colonies: Canada, India, and Pakistan. As a response, the British government passed the British Nationality Act in 1948, under which the inhabitants of the former British Empire maintained their status as British subjects, and being members of the Commonwealth, were free to migrate, settle and take up employment in the UK. They possessed, therefore, a "dual citizenship" of a kind (cf. Spencer, 1997). The liberal policies regulating the influx of foreigners were tightly linked, as has been mentioned, to the necessity of obtaining a labour force for the rapidly growing economy. 
The tightening of legal regulations concerning immigration was associated with the escalation of ethnicity-related social conflict in the late 1950s. The riots of August and September 1958 in Nottingham and London's Notting Hill provided an impulse for legal changes. On 21 July 1962, the Commonwealth Immigrants Act came into effect, introducing three categories of entry vouchers:

- category A was granted to those who had been guaranteed a job in Britain;

- category B referred to immigrants possessing qualifications that were in demand on the labour market;

- category $\mathrm{C}$ meant a possibility of obtaining an entry pass depending on the needs of the British economy.

The introduction of the Commonwealth Immigrants Act had an opposite effect to the one desired. There was a large-scale "beat-ban rush." All at once, foreign workers brought their families to the Isles. The British authorities reacted by abolishing the voucher system in 1965 and limiting the possibility of bringing relatives and children over the age of sixteen.

The freedom of establishment in Great Britain for Commonwealth citizens stopped with the Immigration Act of 1971. It introduced two categories of citizens:

- partials, or citizens of Britain or the Commonwealth, born in the UK or naturalized, with parents and grandparents born or naturalized in the UK. This group also included individuals residing in the UK for the past five years;

- non-partials, in turn, were those who could participate in the labour market but were not entitled to bring their families.

In 1980, the adoption of the Primary Purpose Rule prevented immigrants from bringing their partners or spouses unless they could prove that the marriage was not "fictitious," concluded for the purpose of gaining a residence permit. Citizenship law was revised in 1983. The abolition of the unconditional law of jus soli meant that citizenship could only be obtained by a child born in the United Kingdom to a parent who was a holder of British citizenship or an unconditional residence permit.

A debate on the necessity of developing a specific model of immigrant integration was initiated by Minister of the Interior, Roy Jenkins. His speech of 1966 outlined an integration process which, according to him, could never involve an equalizing process of uniformization, but rather cultural diversity combined with equal opportunities, introduced in an atmosphere of mutual tolerance (Jenkins, 1970, p. 267).

Matters relating to the integration of immigrants were entrusted to the National Committee for Commonwealth Immigrants established in March 1964, composed of representatives of immigrant groups. An accomplishment of the Committee was the development of regulations preventing racial discrimination:

- The Race Relation Act of 1965;

- The Race Relation Act of 1968;

- The Race Relation Act of 1976.

The aforementioned acts set out principles for the treatment of persons of different race by fellow citizens and governmental services. The acts also established institutions to protect racial equality.

The basic anti-discrimination principles adopted in the UK included: 
- abolition of restrictions on access to public areas (hotels, pubs, restaurants, cinemas), public transport, or any places managed by public authorities;

- incitement to racial hatred was deemed to be a criminal offence;

- prohibition of discrimination in employment, the provision of goods, services or assistance, in trade unions, and in advertising;

- prohibition of discrimination as part of housing policies and in the lease of commercial premises;

- prohibition of discrimination in education and vocational training.

The Act of 1965 established the Race Relations Board, where citizens could submit complaints, with the Board reporting any violations of anti-discrimination laws to the Attorney General.

The Act of 1968 founded the Community Relations Commission, which would operate primarily at the local level and supervise local community associations.

Under the Act of 1976, the Commission of Race Equality was established, replacing the former two institutions. Its basic aims included:

- eliminating racial discrimination;

- promoting equal opportunities and good relations among people from different ethnic backgrounds;

- assessing the effectiveness of the Act of 1976.

Moreover, the Commission was authorized to refer cases to the court and to conduct formal investigations into violations of the Act. Committees for Racial Equality were established at a local level.

\section{British society and the issue of multiculturalism}

A public opinion poll conducted in 2010 by Populus on behalf of SET (Searchlight Educational Trust) on a sample of 5054 respondents gave reason to believe that opinions about multiculturalism are greatly divided in British society. Researchers identified 6 groups holding diverse views towards race and ethnicity (Farrar, 2012, p. 7-23).

Those fully supporting multiculturalism (Confident Multiculturalists), who represent 8 percent of the population, have attained a high level of education, are self-confident, and satisfied with their lives. Members of this group vote for the Labour Party, the Liberal Democrats, or the Greens.

Those with strong liberal views (Mainstream Liberals), mainly university graduates, have an optimistic outlook on life and are highly motivated. This group, representing 16 percent of the population, sees immigration as a benefit to the country. They are slightly less avid supporters of multiculturalism than the previous group (Confident Multiculturalists), but they vote for the same parties.

The third group, made up of those showing an ambivalent attitude to multiculturalism (Identity Ambivalents), represents 28 percent of the population. These people have a less optimistic outlook on life and are unsure of their financial stability. Most represent the working class. This group contains Muslims, Blacks, and other minority groups. Among Identity Ambivalents, about 37 percent vote for the Labour Party, but most do not take part in elections. 
Another group is comprised of the Culturally Concerned, who represents 24 percent of the population. Among them are mainly professionals and managers, who have a better financial standing than members of other groups and are of advanced age. This group is concerned about the impact immigration could have on the national identity. They fear that the integration of immigrants into British society might fail. 42 percent of them support the Conservative Party.

Those who conceal their hostility towards different cultures (Latent Hostiles) represent 10 percent of the population and are mostly older people without a university education. They originate mainly from the working class and show a pessimistic attitude towards their future. They believe that immigrants are "undermining" British culture and slowing down economic progress. In this group, 29 percent support the far-right British National Party.

The final group is actively hostile towards the policy of multiculturalism (Active Enmity) and represents 13 percent of the population. This category comprises, in addition to the middle-class, uneducated and unemployed individuals. They are hostile to any ethnic or religious group different to their own. Many justify the use of violence as a way of defending their rights. 56 percent of them support the British National Party (Farrar, 2012, p. 7-23).

In conclusion, only 24 percent of the British society approve of the multicultural policy of immigrant integration, while 23 percent are strongly opposed. Over half of the respondents have no opinion on the issue.

\section{British society in a state of super-diversity}

In the second decade of the 21 st century, British society reached a stage of "super-diversity." With the current intricate mosaic of races, religions and nationalities, the multiculturalism policy has ceased to apply. Steven Vertovec, who coined the term super-diversity, claims that new, more fragmented immigrant groups are currently forming. What differentiates those groups from the immigrant groups of the late 20th century is the fact that they are much less organized and more diversified in terms of legal status, language and religion. Immigrants no longer only arrive into the UK from former colonies, historically associated with Britain, but often already have experience living in other EU countries (cf. Vertovec, 1999, 2004). Vertovec also points out that new relationships give rise to new patterns of inequality and prejudice against recent immigrants, now expressed by both the British and by minorities who had settled in the UK previously. The researcher argues that super-diversity has led to the emergence of new patterns of segregation - a new definition of "whiteness."

The terrorist attacks of 7 July 2005 became the turning point which intensified the debate on developing a new model of immigrant integration. In the autumn of 2006, the Commission for Racial Equality headed by Trevor Phillips proposed a new concept of integration, based on three pillars:

I - equality, promoted by an anti-exclusion policy;

II - interactions, mainly through sports, summer camps and schools; 
III - participation, including an increased minority participation in politics, for example through increasing the representation of minorities among Members of Parliament from 15 to 50 .

Great Britain was faced with the need to develop a new model, covering not only the integration of immigrants but also - as Gordon Brown said in 2006 - the necessity of developing a new concept of Britishness. The Philips Commission concluded that Britishness should be constructed around liberal values such as commitment to democracy, freedom of speech, freedom of action and national values: common tradition and language. Philips also advocated stricter separation between public and private spheres. The next step was the creation of the Commission on Integration and Cohesion in 2006. Ruth Kelly, Secretary of State for Communities under the government of Gordon Brown, stressed that the ideas and policies of the government should not be concerned with special treatment of ethnic and religious minorities, since this would not be conducive to social cohesion. She pointed out that even in mutual tolerance there are non-negotiable rules which must be recognized by all groups, both the newcomers and the locals. In 2007, the Commission released a report entitled "Our Shared Future." One of the key findings of the report was the disassociation of the concepts of integration and struggle against inequality and discrimination. The Commission adopted a program for the integration of ethnic and religious minorities, which is currently being implemented. The program involves:

- creating a new national holiday celebrating the cohesion of the British nation (Community Day);

- negotiations with political parties in order to persuade them to increase minority representation on electoral lists;

- obligating companies to grant employees additional three days of paid leave for religious practice;

- employers should also organize English classes for their employees, and offices should reduce the number of translated documents issued to immigrants in order to increase their motivation to learn English;

- the state should exercise greater control over the curricula of religious schools;

- the program also proposed that the symbolic meaning of citizenship ceremonies be emphasized and that they be held for school-age youth (Our shared future).

The program considers language to be the main factor promoting national community. In the United Kingdom, the multicultural model of ethnic relations has not been completely rejected, but a stronger emphasis was placed on the need to maintain social cohesion and build a strong national identity.

A significant change introduced by the Labour government was the adoption of the Borders, Citizenship and Immigration Act of 2009. It aimed to simplify immigration laws, strengthen border security and reform the naturalization process. Before 2009, naturalization was a relatively quick process, taking three years for first-generation migrants, and involved a test in the English language, political system and civil rights. The most important changes in the regulations mainly concern the introduction of a trial period for potential future citizens of the United Kingdom. During this period, the candidate should demonstrate not only their "good character," but also active participation in the life of the local community and efforts made for its benefit. These provisions may 
be said to embody the concept of "earned citizenship," whereby nationality is granted as a reward for certain efforts that benefit the public (Borders).

\section{Conclusion}

The coming of the Conservative Party into power following the parliamentary elections of 2010 did not alter the main line of immigrant integration policy developed by the Labour government. The policy of multiculturalism in the integration of immigrants was maintained, despite strong criticism from some circles. The main points of focus are, as before, anti-discrimination legislation, the promotion of social cohesion, and more recently, migration management strategy. Drawing on the experience of countries such as Australia and Canada, the new government promotes a highly selective migration policy aimed at maximizing the benefits to the UK labour market and favouring highly skilled migrants. However, Great Britain is faced with the need to develop a new model, encompassing not only immigrant integration but also - as Gordon Brown said in 2006 - the necessity of developing a new concept of Britishness.

\section{Bibliography}

Borders, Citizenship and Immigration Act 2009, http://www.legislation.gov.uk/ukpga/2009/11/pdf, 10.07.2014.

British Nationality Act 1948, http://www.legislation.gov.uk/ukpga/Geo6/11-12/56/fulltext_en.pdf, 10.07.2014.

Carrera S. (2005), Integration as a Process of Inclusion for Migrants? The Case of Long-Term Residents in the EU, CEPS Working Document 219, Center for European Policy Studies, Bruksela.

Castles S. (2010), Migration and Community Formation under Conditions of Globalisation, conferenrence: "Reinventing Society in the New Economy", Toronto, 9-10 March.

Castles S., Miller M. J. (2003), The Age of Migration. International Population Movements in the Modern World, The Guilford Press, New York.

Castles S., Miller M. J. (2011), Migracje we wspótczesnym świecie, Wydawnictwo Naukowe PWN, Warszawa.

Chase E. P. (1947), Government by consultation in the British Commonwealth, "The Journal of Politics", no 2.

Cohen A. (1959), British Policy in Changing Africa, Northwestern University Press, London.

Commonwealth Immigration Act (1962), http://webarchive.nationalarchives.gov.uk/+/http:// www.movinghere.org.uk/deliveryfiles/pro/Commonwealth_Immigration_Act_1962/0/8.pdf, 10.07.2014.

Farrar M. (2012), Multiculturalism in the UK: A Contested Discourse, in: Islam in The West. Key Issues in Multiculturalism, eds. M. Farrar, S. Robinson, Y. Walli, P. Wetherly, Palgrave Macmillan, London.

Giddens A. (2006), Socjologia, Wydawnictwo Naukowe PWN, Warszawa.

Jenkins R. (1970), Essays and Speeches, Collins, London. 
Kiwerska J. (1989), Rozpad imperium brytyjskiego w Afryce, PWN, Warszawa.

Lee J. M. (1967), Colonial Development and Good Government. A study of the ideas expressed by the British official classes in planning decolonization 1939-1964, Oxford University Press, Oxford.

Mansergh N. (1955), The Multi Racial Commonwealth: A Report. Proceedings of the Fifth Unofficial Commonwealth Relations Conference Held at Lahore, Pakistan, 17-27 March 1954, Royal Institute of International Affairs, London.

Mansergh N. (ed.) (1953), Documents and Speeches on British Commonwealth Affairs 1931-1952, t. III, Oxford University Press, London-New York.

Miller J. (1974), Survey of Commonwealth Affairs. Problem of expansion and attrition 1953-1969, London.

Our shared future, raport Komisji Integracji i Spójności Społecznej, http://resources.cohesioninstitute.org.uk/Publications/Documents/Document/DownloadDocumentsFile.aspx?recordId= $18 \&$ file=PDFversion, 10.07.2014.

Race Relation Act (1968), http://www.legislation.gov.uk/ukpga/1968/71/pdfs/ukpga_19680071_en.pdf, 10.07.2014.

Race Relation Act (1976), http://www.legislation.gov.uk/ukpga/1976/74, 10.07.2014.

Stownik historii politycznej świata 1901-2005 (2006), pod red. B. Bankowicz, M. Bankowicza, A. Dudka, Wydawnictwo Uniwersytetu Jagiellońskiego, Kraków 2006.

Spencer I. R. G. (1997), British Immigration Policy since 1939. The Making of Muliti-Racial Britain, Routledge, London.

Vertovec S. (1999), Conceiving and Researching Transnationalism, "Ethnic and Racial Studies", no 22.

Vertovec S. (2004), Migrant Transnationalism and Modes of Transformation, "International Migration Review", no 38.

Vertovec S. (2006), The Emergence of Super-diversity in Britain, Working Paper no 25 for the Centre on Migration, Policy and Society, Oxford.

Włoch R. (2011), Polityka integracji muzulmanów we Francji i Wielkiej Brytanii, Wydawnictwa Uniwersytetu Warszawskiego, Warszawa.

Young C. (1970), Decolonization in Africa, in: Colonialism in Africa, t. II: The History and Politics of Colonialism 1914-1960, Cambridge University Press, Cambridge.

\section{Summary}

The paper presents the evolution of the British model of immigrant integration after World War II. It is a historical and political analysis. The author indicates the key elements of the British approach to decolonisation which were translated into concrete legal acts regulating the lives of the Commonwealth residents and immigrants arriving in the UK. The paper also discusses different dimensions of the integration of immigrants into British society. The analysis indicates that the multicultural model of immigrant integration adopted after World War II has been found to be dysfunctional, as British society has reached a state of super-diversity, becoming a very complex mosaic of races, religions and nationalities.

Keywords: migration, Great Britain, integration model, immigrant 


\title{
Ewolucja brytyjskiej polityki integracji imigrantów po II wojnie światowej: perspektywa historyczno-politologiczna
}

\begin{abstract}
Streszczenie
W artykule ukazana została ewolucja brytyjskiego modelu integracji imigrantów po II wojnie światowej. Artykuł stanowi analizę historyczno-politologiczną. Autorka wskazuje kluczowe elementy brytyjskiego podejścia do procesu dekolonizacji, które przełożyły się na konkretne regulacje prawne odnoszące się do mieszkańców Commonwealthu i imigrantów napływających do Wielkiej Brytanii. W artykule omówione zostały również płaszczyzny integracji imigrantów ze społeczeństwem brytyjskim. Analiza wskazuje, iż przyjęty po II wojnie światowej multikulturowy model integracji imigrantów został zakwestionowany jako dysfunkcyjny w obliczu osiągnięcia przez brytyjskie społeczeństwo stadium nadróżnorodności (super-diversity), czyli bardzo skomplikowanej mozaiki ras, religii i narodowości.
\end{abstract}

Słowa kluczowe: migracja, Wielka Brytania, model integracji, imigrant 